\title{
On the æthereal compounds of terebic acid
}

\section{M.A. Caillot}

To cite this article: M.A. Caillot (1850) On the æthereal compounds of terebic acid, Philosophical Magazine Series 3, 36:240, 77-78, DOI: 10.1080/14786445008646427

To link to this article: http://dx.doi.org/10.1080/14786445008646427

曲 Published online: 30 Apr 2009.

Submit your article to this journal $2 \pi$

Џ Article views: 2

Q View related articles $₫$ 
The formula of the metaterebates is $\mathrm{C}^{14} \mathrm{H}^{13} \mathrm{O}^{11}, 2 \mathrm{MO}$; those obtained by the author are the metaterebates of barytes, strontia, potash, soda, magnesia and manganese. They are perfectly soluble in water, and most of them crystallizable. They are formed, either by neutralizing the acid with the bases, or by double decomposition. The metaterebates of zinc, nickel and iron, obtained by double decomposition, are almost immediately converted into monobasic terebates, and deposit half their bases.

The formula of the diaterebates is $\mathrm{C}^{14} \mathrm{H}^{10} \mathrm{O}^{8}, 2 \mathrm{MO}$. M. Caillot has obtained the salts of lime, silver, copper and lead. All may be prepared by double decomposition, but the diaterebate of lime may be obtained by direct means. 'This last salt is soluble and crystallizable; the others are nearly insoluble.

C. Compounds of Lead.-Besides the terebate of lead and the diaterebate, M. Caillot has obtained several other remarkable compounds. By dissolving two equivalents of oxide of lead in an equivalent of terebic acid, there is composed a salt $\mathrm{C}^{14} \mathrm{H}^{8} \mathrm{O}^{6} \mathrm{PbO}, 2 \mathrm{HO}$, soluble in water in all proportions. This compound can part with two equivalents of water and leave $\mathrm{C}^{14} \mathrm{H}^{8} \mathrm{O}^{6} 2 \mathrm{PbO}, 2 \mathrm{PbO}$.

On dissolving hydrate of lead in terebic acid, or still better, in a concentrated solution of monoterebate of lead, a compound is obtained which is soluble in water in all proportions, $\mathrm{C}^{14} \mathrm{H}^{16} \mathrm{O}^{8} 5 \mathrm{PbO}=\mathrm{C}^{14} \mathrm{H}^{8} \mathrm{O}^{6}$ $5 \mathrm{PbO}, 2 \mathrm{HO}$. By long-continued ebullition the solution deposits a new salt, the formula of which is $\mathrm{C}^{14} \mathrm{H}^{3} \mathrm{O}^{6} 5 \mathrm{PbO}, 2 \mathrm{PbO}$. A cold solution of metaterebate of barytes dissolves a large quantity of the oxides of lead and silver. New compounds are formed, respecting which M. Caillot has promised future communications. From the facts contained in this memoir it may be concluded-

1st. That terebic acid combines with all bases so as to produce monobasic salts.

2nd. That when there is an excess of an alkaline base, this acid combines with various proportions of water according to the nature of the bases, to constitute two new acids, namely, the diaterebic and metaterebic, both of which are bibasic.

3rd. That oxide of lead forms with the terebic acid several compounds, among which are two that are without analogy in chemistry, and which the author is inclined to consider as performing the functions of acids.

4 th. That the combination of water in the diaterebates and the metaterebates appears to be the essential condition of the bibasity of these salts. The author is of opinion that this proposition acquires additional probability, on considering the facts observed respecting the phosphates by Mr. Graham, and those respecting the phosphites and hypophosphites by M. Wurtz, and the acids of antimony and tin by M. Fremy.-I'Institut, Novembre 7, 1849 .

\section{ON THE ATHEREAL COMPOUNDS OF TEREBIC ACID.}

BY M. A. CAILLOT,

The results obtained by the author with re sect to the composition of the terebates, induced him to direct his researches to the æthereal 
compounds of terebic acid. Hitherto he has obtained only the compounds which correspond to the monobasic terebates; they are represented by the general formula $\mathrm{C}^{14} \mathrm{H}^{9} \mathrm{O}^{7}\left(\mathrm{C}^{\mathrm{m}} \mathrm{H}^{\mathrm{n}}\right) \mathrm{O}=\mathrm{C}^{14} \mathrm{H}^{8} \mathrm{O}^{6}, \mathrm{HO}$, $\left(\mathrm{C}^{\mathrm{m}} \mathrm{H}^{\mathrm{n}}\right) \mathrm{O}$. He has obtained the vinic, amylic and methylic compounds, which in their general physical properties much resemble others; thus at common temperatures they are liquid, oleaginous, slightly soluble in water; they have a hot, acrid, bitter, but not an acid taste; the vinic and amylic compounds may be distilled without undergoing decomposition. M. Caillot was able to determine the density of the vapour of the vinic compound : it confirmed the results of the elementary analyses. The methylic compound is altered by distillation.

These compounds act with bases like acids, but the salts which they produce are not permanent. The terebovinate proper for analysis was obtained with great difficulty ; its formula is $\mathrm{C}^{14} \mathrm{H}^{8} \mathrm{O}^{6}, \mathrm{BaO}$, $\mathrm{C}^{4} \mathrm{H}^{5} \mathrm{O}$. With the slightest increase of temperature these vinic salts reproduce the alcohol from which they are formed, and generate a bibasic metaterebate, half of the vinic acid being set free. This transformation may be represented by the following equation :

$2\left(\mathrm{C}^{44} \mathrm{H}^{8} \mathrm{O}^{6}, \mathrm{BaO}, \mathrm{C}^{4} \mathrm{H}^{5} \mathrm{O}\right)+7 \mathrm{HO},\left(\mathrm{C}^{14} \mathrm{H}^{13} \mathrm{O}^{11} 2 \mathrm{BaO}\right)+\mathrm{C}^{4} \mathrm{H}^{6} \mathrm{O}^{2}$ $+\left(\mathrm{C}^{14} \mathrm{H}^{8} \mathrm{O}^{6}, \mathrm{HO}, \mathrm{C}^{4} \mathrm{H}^{5} \mathrm{O}\right)$.

The property which terebic acid possesses of forming vinic acid, seems to indicate that this acid may produce bibasic anhydrous salts, of the formula $\mathrm{C}^{44} \mathrm{H}^{8} \mathrm{O}^{6} 2 \mathrm{MO}$ - $L$ 'Institut, Novembre 7,1849 .

\section{PARATARTARIC ACID.}

M. Kestner states that this acid was produced for some years, or from 1822 to 1824 nearly. At this time the tartrates were saturated with carbonate of lime, and the remainder of the tartrates were precipitated by chloride of calcium; the tartrate of lime was decomposed by great excess of sulphuric acid, evaporation was effected over the naked fire, and the solutions of tartaric acid were decolorized by a current of chlorine gas; this operation was performed cold, and it was then remarked, and more especially in winter, that crystals of parataric acid were formed which were carefully separated, because they rendered the crystallization of the tartaric acid irregular when they remained mixed with it.

M. Kestner states that since the above-stated period, tartar has been saturated by caustic lime, and the tartrate of lime formed is decomposed by a slight excess of sulphuric acid; no chlorine is now employed to decolorize the liquors, and no trace of parataric acid is now ohtained.

It is stated by $M$. Kestner that he is entirely ignorant whether the circumstances which he has stated have produced the paratartaric acid: he has never been able to produce it, neither by the agency of sulphuric acid, even at high temperatures and heating them for a long time together, nor by the action of chlorine. Nor has he succeeded in extracting it directly from tartar, although the attempt has been made on considerable quantities. 